\title{
Responsibilities of Multinational Corporations on Environmental Issues
}

\author{
Mahsa Hosseini Moghaddam ${ }^{1} \&$ Ali Zare $^{2}$ \\ ${ }^{1}$ PhD Student in Public International Law, Department of Public and International Law, Faculty of Law and \\ Political Sciences, Science and Research Branch, Islamic Azad University, Tehran, Iran \\ ${ }^{2}$ Assistant Professor, Department of Private Law, Faculty of Law and Political Sciences, Science and Research \\ Branch, Islamic Azad University, Tehran, Iran \\ Correspondence: Ali Zare, Assistant Professor, Department of Private Law, Faculty of Law and Political \\ Sciences, Science and Research Branch, Islamic Azad University, Tehran, Iran. E-mail: alizare@srbiau.ac.ir
}

Received: May 7, 2016

doi:10.5539/jpl.v10n5p78
Accepted: June 27, $2016 \quad$ Online Published: November 29, 2017

URL: https://doi.org/10.5539/jpl.v10n5p78

\begin{abstract}
Multinational corporations play more roles in social and cultural and political issues in this century. This growing trend in multinational companies, has led the international law, talk about "corporate social responsibility". One of the most important aspects of CSR is environmental issues. The question is that is there enough regulatory basis- at the local or international level- to guaranty responsible behavior of these companies. And in the cases of environmental damages which parts of a company should be responsive and compensate damages. Perhaps the assignment of responsibility in the actions against multinational companies on environmental issues is not too difficult; the reason is that losses are objective and external. Note that in many deserving cases, harm to the environmental rights is a violation of human rights, particularly the third generation of human rights.
\end{abstract}

Keywords: environmental responsibility, social responsibility, multinational corporations, liability of parent company

\section{Introduction}

Multinational companies operate in different countries under various legal systems. Their activities are governed by different and even opposing rules and regulations, and no specific and unique legal unit can control their activities. Thus the specific characteristics of multinational companies have caused unique legal subjects that do not apply to other companies and institutions. These companies actually are dominant on trade, and in many cases - on extraction, and utilization of natural resources, equipment that destroys forests, water sources, and producing toxic waste and other harmful and unsafe products. The responsibility of these companies, in a new stage of expansion, includes all human beings. At this stage, the United Nations attempts to compose the regiment that oversees the activities of these companies. The compilation of the rough draft of the regulations governing multinational companies, and the establishment of a post special to the secretary of multinational company affairs and human rights, are some of the actions that provide the organized cooperation of states, multinational companies, non-governmental organizations, environmentalists, and human rights advocates. The responsibility of these companies has expanded in its depth, as well as its expansion on the surface. Depth expansion refers to the fact that their responsibility has grown to include environmental and ethical issues in addition to just economic and social responsibility. Hence, in this article, regulations that can cover these liabilities regarding environmental issues will be discussed. Since international detriments can be very complex, decisions made by parent companies can affect the environmental management methods of companies operating in other countries directly (Anderson, 2002: 405). Hence, one of the subjects covered in this article is the possibility to link responsibility to the parent company regarding the actions of subsidiary companies in preventing non-recompense of environmental damages. In this article, regarding the environmental liabilities of the company, minimizing the ecological effects of organizational operations (via methods such as: preventing environmental pollution, assigning resources to environmental protection, and voluntary submission to environmental regulations) are emphasized. Furthermore, in order to reduce damages to the environment, solutions such as environmental education, waste management, environmental utilization, and environmental 
services are considered (Kurzyna, 2014: 123).

\section{Implementing Dual Standards}

Regulations of industrialized countries are usually stricter than the regulations of developing countries. In the past two decades, it has been strongly emphasized that multinational companies that operate in developing countries, are governed by less strict environmental standards compared to standards in the source country. These companies cannot be held liable for environmental damages from their operation, as long as they operate based on the environmental regulations of developing countries, even if it is possible to decrease or prevent such damages by utilizing higher environmental standards. Nonetheless, damages to the environment do not just affect the host country; it causes a global problem. The rate of increasing pollution and the hazards it causes show the necessity to implement higher environmental standards is developing countries. This objective is reachable by the international implementation of environmental regulations by home countries of multinational companies (Mousavi, 2011:341).

Recently, multinational companies have started using comparable methods regarding environmental issues. Generally, these companies generate domestic environmental standards - that are equal to or more than all standards in the main regions of investment; and all equipment across the world must conform to these standards (Morimoto, 2005:136). However, the number of multinational companies that have accepted such standards is very little, and it seems that dual standards are dominant. Due to diminishing expenses of environmental protection, multinational companies can increase their short-term profits, and consumers, especially those in advanced countries, can have access to less expensive products. But we should not close our eyes on the long-term cost of compensating for the damages to the earth caused by the short-term profits (Morimoto, 2005:139).

\section{Beneficiaries of the Environmental Responsibility of Companies}

In the discussion of the connection between beneficiaries and social responsibility, three related aspects that determine the benefits of various groups, should be pointed out: profit, the people, and the planet earth. Important beneficiaries in the area of generating income are insurance companies, banks, investors, and shareholders. Regarding environmental protection, important entities are: Non-governmental environmental organizations, small landowners, local governments, and officials engaged in environmental protection. It may also be claimed that nature is a beneficiary of social responsibility, especially regarding the variation of life and environmental protection. Regarding social aspects, in addition to managers and employees in civil societies and public units, people throughout the world and even future generations are considered part of the beneficiaries. Any beneficiary belonging to shareholders, personnel, competitors, consumers, and local society have the right to interfere in the activities of the company. This is because the company is coexisting next to the other members of the society (Kurzyna, 2014: 125).

\section{Current Regulations}

Since some of the environmental damages are caused by the private sector, limiting the international responsibility for environmental damages to states results in the lack of response to many environmental damages; hence one of the positive changes in international responsibility for environmental damages is the expansion of this responsibility to include the private sector. Generally, these companies generate domestic environmental standards - that are equal to or more than all standards in main regions of investment; and all equipment across the world must conform to these standards. Generally, these companies generate domestic environmental standards - that are equal to or more than all standards in the main regions of investment; and all equipment across the world must conform to these standards. Generally, these companies generate domestic environmental standards - that are equal to or more than all standards in the main regions of investment; and all equipment across the world must conform to these standards (Ghasemzadeh, 2007:109).

Generally, these companies generate domestic environmental standards - that are equal to or more than all standards in the main regions of investment; and all equipment across the world must conform to these standards. These companies cannot be held liable for environmental damages from their operation, as long as they operate based on the environmental regulations of developing countries, even if it is possible to decrease or prevent such damages by utilizing higher environmental standards. These companies cannot be held liable for environmental damages from their operation, as long as they operate based on the environmental regulations of developing countries, even if it is possible to decrease or prevent such damages by utilizing higher environmental standards. These companies cannot be held liable for environmental damages from their operation, as long as they operate based on the environmental regulations of developing countries, even if it is possible to decrease or prevent such damages by utilizing higher environmental standards. These companies cannot be held liable for environmental 
damages from their operation, as long as they operate based on the environmental regulations of developing countries, even if it is possible to decrease or prevent such damages by utilizing higher environmental standards. However, the suggestions were declined and this was the final attempt for lawmaking in this area. After that, international lawmakers concentrated on supporting foreign investments, while staying away from international regulations regarding multinational companies (Revesz, 2004:29). A sign of this substitution in objectives is reaching "soft" and unbinding law in relation to rights and duties of multinational companies. ${ }^{1}$

In 1992, the International Standards Organization (ISO) was requested to act more extensively regarding the compilation of environmental management standards. Based on this request, International Standards Organization formed a consultation group, named SAGE, comprised of representatives from twenty countries, eleven international organizations, and more than 100 environmental management experts, and analyzed the following subjects:

- Encouraging companies to develop a general approach to environmental management

- Enhancing companies' abilities to improve environmental measures to prevent environmental pollution

- Improving commercial transactions on an international level and eliminating commercial obstacles by forming standards for evaluating companies' environmental performance

- Predicting problems that can be caused by the compilation of international environmental standards.

The results of this analysis showed the necessity to form international environmental standards. The International Standards Organization, in 1993, formed a technical committee titled environmental management to compile environmental management standards, and based on this, on August 1996 a set of six standards (from the ISO14000 series), was published after extensive scientific analysis.

ISO14001 standards describe the needs of an environmental management system, so that it can be used in companies along with other management standards, such as ISO9000 series standards for quality management, safety standards, and other standards. In this standard, there are frameworks determined as movement basis for the company, and it is the responsibility of the companies and organizations utilizing them to analyze them considering the type and the form of their activities and to create the settings required for this management system.

ISO14001 standards are compiled such that they are applicable and executable for all small and large organizations, even if they are not similar geographically, culturally, and socially.

OECD, ${ }^{2}$ in 1976, with its statement regarding international investments and multinational companies, tried to be the pioneer in this regard. This statement included instructions for multinational companies. Finally, towards the end of the century, this organization approved a series of guidelines for the environmental responsibility of companies. The revised guidelines published in 2000 included an invitation to multinational companies to implement standards of high quality for the environment and to improve the enactment of the environmental policies of the company. To fight bribery in international transactions, the convention of this organization vilified bribing governmental officials for gaining profits and advantages, and exposed companies and their managers to more legal action. This pact, enacted in 1999, placed a strong and effective tool at the disposal of OECD. Considering the economic and official situation in developing countries, this convention can improve fleeing from law in these societies (Adeyeye, 2012: 15).

The other attempt in this area is the UN GLOBAL COMPACT, which is an educational network put together with the cooperation of the main agencies of the United Nations, companies, trade institutions, non-governmental organizations, and trade, worker, or syndicate unions. This pact consists of ten principles which are geared toward performing responsible actions based on human rights, work standards, and functions harmonious with the environment, and fighting corruption. This document requires companies to abide by the framework created by these ten principles, all of which are based on international commitments between states.

Principles 7 and 8 require companies to employ a preventive approach toward environmental challenges. And use innovative solutions to heighten responsibility toward environmental issues. In principle 9 requests that companies strengthen and encourage the advancement and proliferation of technologies harmonious with the environment.

\footnotetext{
${ }^{1}$ The International Labour Organization (ILO) Tripartite Declaration of Principles concerning Multinational Enterprises and Social Policy, the OECD Guidelines on Multinational Enterprises, and the United Nations Global Compact.

${ }^{2}$ Organization for Economic Cooperation and Development
} 
The other document is the statement by the world constant development committee, which states: "We agree that the private sector- including large and small companies, considering their legal activities- are obligated to cooperate in the constant development of societies. We unanimously agree that the companies of the private sector must be held responsible, and this responsibility should be exercised in a stable and clear setting." The results of the Johannesburg committee are quite different than the conditions of the world stable systems. Today's capitalistic systems demand constant economic growth, whereas the stability principle makes us accept that in a limited world this is not attained easily.

Agenda 21 is another document regarding this matter. In section 8, titled "Combining the environment and development", it requests that companies and nations to implement the expenses of supporting the environment, destroying and rebuilding it, in their decision-making, and perform the required research for the calculation of these expenses without delay, and create conditions that regard these matters at every level of decision-making. In section 30, titled "Trade and industry", that trade and industry through international companies create the closest connection between advanced countries and developing countries. 350 large international companies that are responsible for 40 percent of the production in the world are in fact the main pillars of the effects of technology on the environment. Some of these companies, via the "Constant development commercial council", are pioneers in the utilization of calculations that include the environmental expense of using environmental units and their restoration.

It is worth noting that although there are many environmental treaties in the international level, these treaties bind states and not the companies directly. Hence, the actions performed regarding companies are very inefficient.

There are also some attempts, on an internal level, by the countries. The 2003 bill of responsibility of companies in Britain, which defines duties for companies regarding descriptive reporting, a duty based on international consultation with subsidiaries that are affected more than company shareholders, and the duties of the board of directors, to consider the social and environmental effects of international activities, and legal commitments based on the payment of damages to individuals outside the borders (Anderson, 2002: 409).

\section{Responsibility of the Subsidiary Company}

The main obstacle in the way of claimants of injury caused by multinational companies is the outspread of multinational companies throughout the world, such that a single multinational has many branches and subsidiary companies all over the world. Hence, the most important difficulty facing a claimant in executing a sentence against a multinational company is to resolve the obstacles caused by the multitude of legal regulations in countries where the multinational company and its subsidiary companies are based. In fact, today multinational companies usually have a parent company that is based in Western Europe or North America, and the subsidiary branches of these companies operate in developing countries, and usually, damages to individuals are done by the subsidiary branches active in poor countries. The branches of a multinational company operate under different legal jurisdictions. Theoretically, there is no court in any part of the world that rules all aspects of a multinational company that operates in 3 or 4 continents (Anderson, 2002: 412). In most advanced legal systems, the principle of the unique legal character of companies is accepted. Such that if damages are caused to individuals as a result of the actions of a subsidiary company, the limited responsibility theory enables the parent company to be free from any responsibility. The other difficulty is that usually the subsidiary company has limited financial resources and ability for compensating injuries to individuals. Yet, in most legal systems, the limited responsibility theory is implemented uniformly for independent companies and subsidiary companies (Anderson, 2002: 416).

England's legal system has rules regarding the responsibility of subsidiary companies toward subsidiaries. In this legal system, a common responsibility between subsidiary companies and subsidiaries (such as contractor companies) can be accepted only when an active collaboration exists between the two companies, such that the two companies are considered one in regards to responsibility. However, it should be noted that the relation between subsidiary companies and subsidiaries is not comparable to the relation between parent and subsidiary companies.

\section{Liabilities of Parent Companies}

Considering the fact that in most cases the parent company is formed in an advanced country and many of its subsidiaries are formed in developing countries, the question is: "In case damages are caused to individuals as a result of the actions of one of the subsidiary companies, can the parent company be legally prosecuted?" The answer to this question, especially in the cases of human or environmental disasters, is very important, since in these cases the possibility that the subsidiary company is not able to compensate for the damages caused, and the 
possibility to prosecute the parent company becomes a necessity. In this case, the parent company should be held liable to the degree that it has control over the subsidiary company.

The fact is that the limited responsibility theory loses its function when it comes to multinational companies. Affiliated companies are not just independent economic units, but they are part of interwoven pillars that form a multinational company and their actions are harmonious with the whole formation. For example: in many cases, the members of the board of directors of an affiliate company are employees of the parent company. The management of these companies does not operate independently, but in strict accordance with the policies and objectives of the whole formation, and in many cases, affiliated companies just execute the programs designed by the parent company. In many cases, the parent company is directly responsible for guiding the affiliate companies.

Considering the above, we can conclude that an affiliate company, with regards to its structure, is an operative part of the parent company, and is defined as legally independent. Hence, the interweaving of affiliate companies and the parent company, and the affiliate company being part of the official and managerial hierarchy, reiterates the responsibility of the parent company for the actions of the affiliate company.

Based on the principles that exist in the common law system, there is a basic principle titled "responsibility for care", which states that when an entity legally assumes control of the actions of others, they are responsible for the actions of the controlled entity. On the same basis, since the parent company controls and guides the affiliate company based on the nature of their relationship, it is liable for the damages caused by the actions of the affiliate company (Smith, 2010: 29-31).

Although accepting this principle is, in fact, the acceptance of the fact that the parent company and the affiliate company each have their own identity, and this is in contradiction with the principle of Lifting the corporate veil and the unity and solidarity of the responsibility of the company. On the other hand, there are views that the parent company should be held liable for the activities of the affiliate company in any circumstances. The belief that has been formed in some cases is that the affiliated company is considered an agent of the parent company, and not separate independent companies (Badge, 2006: 13-15).

In judiciary systems in India, which is inspired from the legal system in England, the principle of strict responsibility for multinational companies has gradually been accepted. However, this principle has been applied only to those industries that innately attempt dangerous activities. This principle is applied on the basis that multinational factories and companies that attempt inherently dangerous activities, are liable for incidents that happen in the factory and cause injury to lives under all circumstances. The theoretical basis of this view is that by forming factories that are inherently dangerous, a dangerous environment is created, from which the owner gains profit, and therefore has to be liable for the dangers it creates. The source of this view is the Bhopal case. This doctrine is not exclusive to English law; there are cases in American and Australian law there are such principles, and similar inferences are made (Muchlinski, 2007:545). In the 2003 bill regarding the responsibility of companies, a legal system that focused on the parent company was mentioned, whereby the parent company guaranteed that the branches conform to human rights standards. In it, provisions regarding a wide range of punishments, including cash penalties all the way to company closure were included. This bill did not receive enough support and was dismissed (Muchlinski, 2007:552).

Attempts regarding the guaranteeing responsibility of multinational companies for environmental damages in countries that are hosts to their capitals are based on integrity, such that parent companies should be required to make sure that their activities as direct foreign investors in these countries are similar to the standards in the source country (Badge, 2006:21). However, the complex nature of the organizational structure of multinational companies usually resists making them legally liable for international damages. In litigation, for responsibility of the parent company, it is necessary to prove that the duty of overseeing is still in effect in the location where the formation is formed with their control (Badge, 2006:35).

\section{The Possibility of Imposing Responsibility to States}

The other traditional method for compensating for environmental damages caused by multinational companies is the state's international responsibility rules. Since the responsibility of states result from breaking international law by state pillars, and multinational companies are not always private institutions, some believe that the government's responsibility starts when the government controls or keeps a company. Others believe that local governments should accept the responsibility for activities of private companies that use their assistance or their export rights and operate in another country (Morgera, 2009: 71).

In many instances, the difficulty, that the country in which the parent company is located does not have the 
competency to regulate the activities of branches outside its borders, exists. While the source countries, in which the branches are located, do not have any advantages over the parent company that makes much important decision. In such conditions, the multinational company possesses a degree of independence from national discretion that is unique in the world legal system, and there are no means for legal and general responsibility, because decisions are made in the country of the parent company, and activities destructive to the environment occur in a foreign land.

Generally, there are three main factors that prevent the effective execution of environmental regulations in developing countries: The first obstacle is the lack of motivation. Since the national budget of developing countries relies on the activities of multinational companies, legislators are inclined to avoid difficult executive warrants against these companies. The second obstacle is the lack of experience and resources for providing required training for legal and executive officials for the advancement of environmental regulations. The third obstacle is official corruption in less-developed countries, which prevents the efficient and effective implementation of laws (Morimoto, 2005:140).

Based on the recited facts, it seems that nothing can be expected of these countries, and international enforcement of the rules of the source country is the only available solution for making companies abide by the environmental standards and minimizing environmental damages to the host country. Yet, such an international enforcement of domestic laws, based on sovereignty, is difficult. However, based on international law, sovereignty is not an impenetrable barrier. In fact the claim of sovereignty may be indirectly defeated by international regulations. If advanced source countries only enforce control on foreign affiliate companies through regulating the activities of the parent company, it is less arguable (Morimoto, 2005:141). The other solution that is offered is that linking the personal activities of an individual to the state for expressing the international responsibility of that state, can be expressed based on the government's duty to control activities in their area of influence as the warrantor of individual behavior. Hence, state responsibility is created because of the negligence of the government (by not enforcing proper international guidelines) or punishment of some activities of private companies. In this case, international governmental responsibility laws, put the responsibility upon the host state in which the private companies operate, in cases where there are, international environmental damages (Morgera, 2009:82). And, it is possible that the responsibility be placed on the source countries, whose multinational companies who operate outside its borders and have caused environmental damages, based on negligence of their duty, supervising the parent company. In this case, the international element causing environmental damages are the export of dangerous materials and technologies (Morgera, 2009:84).

There are others who believe that for environmental damages, governmental responsibility should be supplementary to civil responsibility. Because a company that observes all local standards and governmental regulations may be free from responsibility, since claims for recompense for damages should be against the state (Morgera, 2009:89).

\section{Connection with Human Rights}

Since the right to have a healthy environment is part of human rights, there are extensive inclinations from the scientific community regarding the enforcement of human rights regulations on multinational companies in the area of the environment, and providing a legal setting for the damages they cause. The UN Special Representative on Human Rights and Multinational Corporations in 2007 clearly stated: "Companies' responsibility is a legal, social, and ethical commitment that is enforced on companies. In his report, he also emphasized companies' responsibility in respecting human rights and not harming human rights as a basic request from all companies, under all circumstances, with the management of the risk of human rights damages and avoiding them. With the difficulties mentioned before, it seems that there is no inclination for changing the execution responsibility from local to international, but naming it "defying human rights", is the beginning of this change. Still, there are two great difficulties regarding the direct enforcement of human rights regulations on companies. First is that human rights are traditionally exclusively against states, and some believe that enforcing some duties on companies in the name of human rights changes the main basis of human rights. Second is that some of the indecent deeds of multinational companies do not completely match our traditional views regarding damages that qualify as defying human rights (Sinden 2007:505). For example, when some die because of eating a poisoned shell, is it a human rights violation? Because of the power and the facilities of these companies, it seems that considering all circumstances regarding human rights cases, we should place these companies in the "duty-holders" group, along with the states (Sinden 2007:507).

Hence, although the environmental responsibility of the companies falls outside the framework of human rights, its regulations cover this as well. The right to a healthy environment is known as the third generation of human 
rights. The environment is very closely connected with the right to health. In a number of cases that have been issued verdicts in the European human rights court regarding the above matter, not observing environmental hygiene is considered the violation of the right to family life (Anderson, 2002: 420).

\section{Conclusion}

Until now, it has been sufficed to soft and flexible solutions and regulations regarding forcing companies to follow environmental regulations. Such solutions and regulations do not create an executive warrant for states, companies, and individuals, and companies are just not responsible with such a view, and ultimately, the feasibility and success of these regulations are very low. The international efforts of the UN, the ILO, and the Organization for Economic Cooperation and Development validate the point that since these companies are not the main successors of international law, a punishment or a decree cannot be placed on them easily, and the agreement of countries is not easily attainable, and only through voluntary acts and encouraging and informative policies, can companies be encouraged. Hence, the enforcement of special regulations regarding observing environmental standards and exerting efforts toward extra support to individuals against these companies, before and after the occurrence of environmental hazards. And, international cooperation for clarifying the responsibilities of these companies and responsible units seems necessary and the existence of an advanced legal mechanism to force these companies to accept and implement strict standards seems inevitable. There are two legal methods for attaining this. The first method is the synchronization of international environmental regulations to create "a uniform arena" for these companies. The second method is regulating the activities of these companies directly by enforcing the domestic environmental rules of the source country to their international activities.

\section{References}

Adeyeye, O. A. (2002). Corporate Social Responsibility of Multinational Corporations in Developing Countries: Perspectives on Anti-Corruption. Cambridge University Press.

Anderson, M. (2002, Spring). Transnational Corporations and Environmental Damage: Is Tort Law the Answer? Washburn Law Journal, 41(3).

Badge, M. (2006, March). Transboundary Accountability for Transnational Corporations: Using Private Civil Claims. Chatham House.

Ghasemzadeh, S. (2007). Analysis of environmental legal aspects with emphasis on prevention of environmental pollution. Allameh periodical, (15).

Kurzyna, B. O. (2014). Corporate Social Responsibility towards the Environment - the Involvement of Polish Enterprises in the Implementation of the Idea of CSR. Journal of Management and Entrepreneurship in Ukraine: the stages of formation and problems of development, 794(2).

Morgera, E. (2009). Corporate accountability in international environmental law. Oxford University Press. https://doi.org/10.1093/acprof:oso/9780199558018.001.0001

Morimoto, T. (2005, December). Growing industrialization and our damaged planet. Utrecht law review, 1(2).

Mousavi, S. F., \& Ghisian, F. (2011, Spring). Compensation of environmental damages in international law. Law periodical, Magazine of the school of law and political science, 41(1).

Muchlinski, T. P. (2007). Multinational Enterprises and the law (2nd ed.). Oxford University Press. https://doi.org/10.1093/law:iic/9780199227969.book.1

Revesz, L. R., \& Stavins, R. N. (2004, May). Environmental law and policy, Prepared for The Handbook of Law and Economics, Resources for the Future, May 2004, p. 29

Sinden, A. (2007, June). Power and responsibility: why human rights should address corporate environmental wrongs, Temple University Legal Studies Research Paper No. 22.

Smith, N. D. (2010, March). The Way We Think: Ethics, Health and the Environment in International Business. Asian Journal of WTO and International Health Law and Policy, 5(1). https://doi.org/10.2139/ssrn.1578267

\section{Copyrights}

Copyright for this article is retained by the author(s), with first publication rights granted to the journal.

This is an open-access article distributed under the terms and conditions of the Creative Commons Attribution license (http://creativecommons.org/licenses/by/4.0/). 